\title{
THE INTERNATIONALIZATION OF SMEs: AN INTEGRATIVE APPROACH
}

\author{
Renata Korsakiené $\dot{1}^{1}$, Manuela Tvaronavičiené $\dot{2}^{2}$ \\ Vilnius Gediminas Technical University, Sauletekio al. 11, LT-10223 Vilnius, Lithuania \\ E-mails: ${ }^{1}$ renatakorsa@takas.lt (correspondingauthor); ${ }^{2}$ manuela@vgtu.lt \\ Received 26 January 2011; accepted 17 August 2011
}

\begin{abstract}
Presented paper aims to compare internationalization of Lithuanian and Norwegian SMEs by exploring the main motives and barriers restricting internationalization process. The authors strive to reveal the patterns of internationalization taking into account the aspects of main theoretical models. The research is based on the main ideas of stage, network and international entrepreneurship approaches. The main motives and barriers restricting internationalization process are based on the previous studies. In order to compare internationalization patterns of Lithuanian and Norwegian SMEs, quantitative research has been performed. The quantitative research is based on responses to a questionnaire embracing various aspects of internationalization. The sample of 300 SMEs was selected taking into consideration previous research. The survey allows concluding that Lithuanian SMEs emphasise geographic proximity as the most important criteria for international market selection. On the other hand, Norwegian SMEs perceive variables of international entrepreneurship theory as the important contributory factors in internationalization process. The authors conclude that Lithuanian SMEs rely on exporting; meanwhile Norwegian SMEs choose subcontracting/licensing or own representative abroad. Hence, Norwegian SMEs are seen at the more advanced stage of internationalization. Authors of the research have elaborated proposals, which are useful for further development of Lithuanian SMEs and take into consideration experience of Norwegian SMEs. The presented paper will contribute to the International Entrepreneurship Forum by providing new insights into further development of SMEs of Lithuania and Norway taking into consideration opportunities and threats.
\end{abstract}

Keywords: internationalization patterns, internationalization motives, internationalization barriers, Lithuania, Norway.

Reference to this paper should be made as follows: Korsakienè, R.; Tvaronavičienè, M. 2012. The internationalization of SMEs: an integrative approach, Journal of Business Economics and Management 13(2): 294-307.

JEL Classification: M10, M13, M16.

\section{Introduction}

Globalisation of economy and intense competition stimulate companies to seek ways of internationalization and significantly contribute to the economic development of nations, industries and productivity. Hence, during last few decades internationalization as a phenomenon has been researched by various scholars and from different points of 
view. Small and medium- sized enterprises (SMEs), playing a significant role in the growth and change of economy, are confronted with international competition and are forced to compete in international markets. Therefore internationalization of SMEs has attracted significant attention of researchers in scientific literature and remains one of the important areas.

Given the situation of today's marketplace, the contribution of SMEs in Lithuania's and Norway's economies is seen as increasing and important. Despite some claims that the internationalization of Norwegian firms is seen as a relatively new phenomenon (Hodne 1993), the research has shown that "the late 1960s should be regarded as the turning point that paved the way for a new strong internationalization wave from the 1980s" (Amdam 2009). On the other hand, research findings related to SMEs activity conclude that context matters as it shapes the role, structure and performance of small firms (Karlsson, Dahlberg 2003). Comparing to Norway SMEs sector in Lithuania has been developing from 1990s, i.e. the period of transition from a system based on state planning to a system characterized by decentralized market allocation and is seen as relatively new. Hence, taking into consideration different development paths of both countries, the attention to the internationalization of SMEs raises an array of questions about motives, barriers and criteria which determine environment selection.

The focus of this paper is to compare internationalization patterns of Lithuanian and Norwegian SMEs by exploring the main factors impacting internationalization process. The authors strive to reveal the patterns of internationalization taking into account the degree of internationalization and the aspects of main theoretical models.

\section{SMEs internationalization theories and models}

The researches linked to SMEs internationalization are seen as relatively new in comparison with internationalization of multinational companies. Notably, a lot of attempts were made in order to clearly define SMEs "internationalization" concept.

Some scholars claim that internationalization means a changing state. Hence, the growth of firm provides a background to internationalization and the concepts of internationalization and growth are interrelated (Buckley, Ghauri 1993). However, Ruzzier et al. state that "some features are unique to internationalization or, at least, there are significant degrees of difference between growth at home and growth internationally" (Ruzzier et al. 2006).

One stream of scholars, striving to define internationalization, put emphasis on process, through which firms are increasingly involved in international markets (Johanson, Vahlne 1977; Welch, Luostarinen 1988). For instance, Welch and Luostarinen state, that the internationalization process is seen as gradual and sequential, through which firms become increasingly committed to, and involved in, international markets.

Meanwhile, Johanson and Vahlne emphasise development of "networks of business relationships in other countries through extension, penetration and integration" (Johanson, Vahlne 1990). Hence, a network analysis is seen as another point of view to firm's international activities (Johanson, Mattson 1993). 
Calof and Beamish, defining internationalization, emphasise the adaptation of firms operations to international environments (Calof, Beamish 1995). However, Ahokangas, inspired by resource- based view, claim that internationalization is seen as "the process of mobilizing, accumulating, and developing resource stocks for international activities" (Ruzzier et al. 2006).

Despite the various approaches to the definition of internationalization, the authors of this paper adopt the view that internationalization is the expansion of firm's operations to foreign markets and agree with the notion that internationalization could result from punctual and independent actions. On the other hand, in order to show the complexity of phenomenon, it is important to discuss the main internationalization theories and models.

It should be noted that internationalization studies are based on several approaches to internationalization, namely stage, learning, contingency and network approaches.

Stage approaches are seen as the earliest group of theories explaining internationalization process. The scholars supporting this approach state that firms start with the modes of entry which require the least commitment of resources and with experience in the market increase their commitment of resources to international activities. For instance, this approach was supported by Cavusgil (1980) and based on progressive reduction of uncertainty. Additionally Reid (1981) has stated that the firms moved from awareness (of export potential) to evolution (of the result of initial exporting) and to acceptance (of exporting as a good thing).

Another group of scholars apply learning theory and state that internationalization is a dynamic process. The studies of Johansson and Wiedersheim-Paul (1975) have laid theoretical framework for the Uppsala model, proposed by Johanson and Vahlne (1977). The model highlights the resource commitment to the foreign markets, market commitment, decisions to commit resources and the performance of current business activities (Johanson, Vahlne 1977). On the other hand, the model has highlighted the relevance of psychic distance in international business decisions. The psychic distance concept was defined as "the sum of factors preventing the flow of information from and to the market" (Johanson, Vahlne 1977). The scholars based on learning theory have focused on an evolutionary and sequential building of foreign commitments over time (De Burca et al. 2004). According to Wiedersheim-Paul et al. firms start their international activities in nearby markets via an intermediary and then on a direct basis. The establishment of a sales subsidiary could be followed by some form of production in international markets (Wiedersheim-Paul et al. 1978).

Contingency approach to internationalization assume that the firm evaluates and responds to an opportunity as it occurs, regardless of whether the market is close in psychic distance terms or whether an advanced mode of entry is required (Okoroafo 1990). Network approaches emphasise the role of linkages and relationships in the internationalization process (Johanson, Mattsson 1993). Chetty and Blankenburg-Holm (2000) state that internationalization takes place in three ways: through creating relationships with partner in new countries, through rising commitment to already established for- 
eign networks and through integrating their positions in networks in various countries. Hence, the success of the firm in entering new markets depends on its position in the network and relationships within current market.

However, in order to explain the phenomenon of SMEs internationalization, the studies support the integration of several approaches. According to scholars, the integration of stage approach, network approach and foreign direct investment theory (including transaction cost analysis) allow us to better understand SMEs internationalization (Covielo, McAuley 1999; Coviello, Martin 1999). In the same way, Etemad and Wright suggested combining a variety of theoretical models, including stage approach, FDI theories and network approach (Etemad, Wright 1999). Bell et al. incorporating stage and network approaches recognise "the explanatory value of contingency approach and allied resource-based theories" (Bell et al. 2003). Likewise, Ruzzier et al. have proposed the integration of process models, innovation models, network approach, resource-based view and international entrepreneurship theory (Ruzzier et al. 2006). Hence, an integrative approach is seen as a new stream in the research of SMEs internationalization.

\section{Internationalization and entrepreneurship}

Studies focusing on explaining SMEs internationalization demonstrate an agreement that SME internationalization is an entrepreneurial activity (Knight 2000; Lu, Beamish 2001). Additionally, scholars considering internationalization of SMEs put emphasis on importance of entrepreneurs, who are seen as the main variables in SMEs internationalization. According to McDougall and Oviatt an increasing number of scholarly investigations into entrepreneurial firms that compete across national borders have enriched and broadened both international business and entrepreneurship research (McDougall, Oviatt 2000).

The shift of interests toward international entrepreneurship has impacted the need to define the concept of international entrepreneurship in a more precise manner. Notably, McDougall and Oviatt have proposed the most frequently used definition and described international entrepreneurship as a combination of innovative, proactive and risk - seeking behavior that crosses national borders and is intended to create value in organizations (McDougall, Oviatt 2000). Later on, they have proposed to define international entrepreneurship as the discovery, evaluation, and exploitation of opportunities across national borders to create future goods and services (McDougall, Oviatt 2005). Notably, the two parts of entrepreneurship are distinguished: 1) opportunities and 2) individuals who strive to exploit these opportunities. Hence, individual and firm entrepreneurial behavior is seen as the basis of foreign market entry.

The studies of internationalization and entrepreneurship have inspired the shift toward "born global firms" which adopt the international focus from the beginning and start rapid and dedicated internationalization. Notably the researches, focusing on the born global phenomenon, concentrate on whether the firms are exporting versus non-exporting and provide empirical evidence of more rapid international activities. For instance, researches carried out in Finland, Norway, Sweden and Denmark proved that the firm's 
domestic markets no longer seem to be as important as "learning place". The scholars state that the stage models fail to explain why such firms operate in international markets rather than just in home markets (McDougall et al. 1994). Additionally, Bell concludes that existing internationalization models do not adequately reflect the underlying factors of the internationalization process in these firms (Bell 1995).

Despite the prevailing critics, the analysis of already established and newly established firms can not ignore the assumptions of stage models. Therefore, the authors of this paper agree with the notion, stating that the firms which do not start international activities after establishment will develop more in line with the stage models of internationalization (Moen, Servais 2002).

\section{Factors impacting internationalization}

Expanding to international markets presents an important opportunity for growth and value creation and exposes unique challenges in addition to common challenges in domestic markets ( $\mathrm{Lu}$, Beamish 2001). Therefore the scholars focusing on the issues of internationalization have strived to define the main stimuli and barriers of internationalization.

The scientific literature concerned with the main motives of internationalization distinguishes several broad areas: decision-maker characteristics; firm-specific factors, environmental factors and firm characteristics (Katsikeas, Piercy 1993). Notably, internal and external stimuli in the decision for internationalization of SMEs are emphasized (Cavusgil, Godiwalla 1982). It is agreed that firms are likely to be motivated by different stimuli that depend on the stage of internationalization.

$\mathrm{Lu}$ and Beamish emphasize that many challenges of internationalization are associated with liability of foreignness and newness (Lu, Beamish 2001). These challenges are seen of higher importance if the target market is dissimilar to the domestic market and if new subsidiaries are established. Hence, SMEs are fostered to acquire new resources and capabilities when entering a foreign market. On the other hand, firms face higher political and operational risks arising from the foreignness of the new environment. Notably, smallness is seen as disadvantage in internationalization, as SMEs often lack resources and capabilities that restrict possibility to capture business opportunities.

Studies focusing on barriers of internationalization by exporters and/or non-exporters distinguish such broad areas: financial, managerial, market - oriented (including both national and international markets), and characteristics of industry and firm (Leonidou 1995; Morgan 1997). It is agreed that barriers of internationalization exist at any stage of internationalization process. On the other hand barriers may differ in intensity depending on the level of internationalization of the individual firm (Cavusgil 1984a; Katsikeas, Morgan 1994).

Fletcher concludes that scientific literature focusing on the main factors impacting internationalization is exhaustive and distinguishes management characteristics, organization characteristics, external impediments or external incentives to engage in business 
overseas (Fletcher 2001). The researches concerned with management characteristics emphasize knowledge of international business, international transactions experience, planning orientation or having strategic approach (Cavusgil, Godiwalla 1982; Fletcher 2001). Meanwhile, the focus on the organizational characteristics embraces willingness to develop products for overseas markets, technological advantage, and willingness to research overseas markets (Bilkey 1985; Evangelista 1994; Cavusgil 1984b). Notably, external impediments are marketing activities by competitors in overseas markets and perception of higher risk in overseas markets, knowledge of the market and how it operates, cost issues, lack of export training and government assistance (Johnston, Czinkota 1985; Bilkey 1985). Finally, the most important external incentives are availability of export incentives from government, oversees demand factors, fall in domestic demand or excess capacity and reduction in costs of production (Kaynak, Kothari 1984; Johnston and Czinkota 1985; Reid 1983).

\section{Methodology}

The above discussion leads to several research questions. The first relates to the factors impacting internationalization of Lithuanian and Norwegian SMEs. The second relates to the main variables determining internationalization of Lithuanian and Norwegian SMEs from the point of stage, network and international entrepreneurship approaches. The REM model developed by Liuhto allows us to set a framework for the analysis of internationalization (Reiljan 2004). The model consists of three dimensions - reason for internationalization, environment selection and modal choice. The reason for internationalization in the original model has strived to compare pro- and anti- internationalization arguments. Meanwhile, environment selection has focused on the comparison between environments (incl. home environment). The modal choice has sought to compare advantages and disadvantages of operational modes. However, striving to reach the set- above objectives, the authors have modified the model (Fig. 1). Hence, the reason for internationalization will compare internal and external motives and barriers to SMEs internationalization in Lithuania and Norway. The environment selection will seek to compare the main criteria, determining environment selection, derived from the stage, network and international entrepreneurship theories. The modal choice will strive to compare operational modes from the point of stage theory.

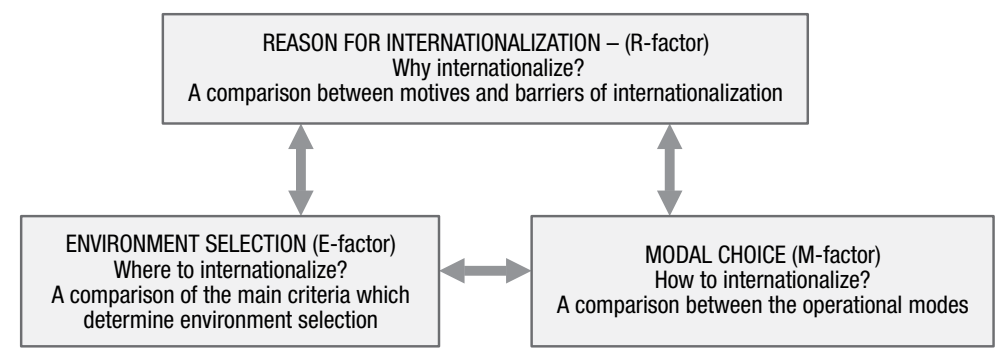

Fig. 1. Internationalization process 
In order to develop a questionnaire, the structured interviews were conducted by interviewing international business experts, representatives of national agencies for development and CEOs of internationalized companies in Lithuania and Norway. The results of interviews allow concluding that Lithuanian SMEs prefer the internationalization into Baltic countries, Russia and Central and Eastern Europe. Meanwhile, Norwegian SMEs prefer to internationalize into Nordic countries, Central and Eastern Europe. The questionnaire was developed and the pilot testing was conducted in 2009 by mailing to 20 international business executives. In 2010 the updated questionnaire was mailed to the population of firms from Lithuania and Norway. The firms were selected according to the Gazelle company list developed by business journal "Verslo zinios" in Lithuania and Dagens Næringsliv in collaboration with credit rating agency Dun \& Bradstreet in Norway. Gazelle Company is a term for the firms with strong finances and a steady increase in turnover over a period of several years. The questionnaire was sent to 300 firms from Lithuania and Norway. Completed questionnaires numbered 75 which is a response rate of $25 \%$ from Lithuanian firms and 86 which is a response rate of $29 \%$ from Norwegian firms. The biggest percentage of respondents was from firms which have 51-250 employees (respectively 46\% from Lithuania and 32\% from Norway). Twenty-four per cent of Lithuanian SMEs and 26\% of Norwegian SMEs were not engaged in some form of international activity. However, their responses were analysed in order to detect motives and barriers of internationalization. Notably, the firms which have filled questionnaires are attributed to different business sectors. However, SMEs which represent furniture and wood processing industry $(21 \%)$, food industry $(14 \%)$ and construction (10\%) industry compose the biggest part of respondents from Lithuania. Meanwhile SMEs which represent information and communication technologies $(19 \%)$, machinery $(10 \%)$ and oil and gas industry $(9 \%)$ compose the biggest part of respondents from Norway.

\section{Results}

The first stage of analysis is related to the factors impacting internationalization of Lithuanian and Norwegian SMEs. These factors were derived from previous research on motives and barriers of internationalization. Questions relating to the internal and external motives were included in the survey instrument. The respondents were asked to rank internal and external motives using Likert scale (where 1 - the least important and 5 - the most important). The results of findings are presented in Table 1.

The obtained results about external motives of internationalization do not indicate differences in attitudes of Norwegian and Lithuanian respondents. It should be noted that the most important external motives impacting internationalization of Lithuanian and Norwegian SMEs are small domestic market, competitive pressure and proximity to customers and suppliers. Notably, small domestic market and competitive pressures that result in profit margins are seen as a powerful inducement impacting firms to enter foreign markets. On the other hand, these motives influence strategic decisions of firms to maintain or enhance competitive position in the market or industry. The standard deviation of small domestic market (respectively 0.78 of Lithuanian SMEs and 0.76 of 
Table 1. External and internal motives of internationalization

\begin{tabular}{lcccc}
\hline \multirow{2}{*}{ Motives of internationalization } & \multicolumn{2}{c}{ Lithuanian SMEs } & \multicolumn{2}{c}{ Norwegian SMEs } \\
\cline { 2 - 5 } & Mean & Stand. deviation & Mean & Stand. deviation \\
\hline Small domestic market & 4.57 & 0.78 & 4.49 & 0.76 \\
\hline Competitive pressure & 4.48 & 0.87 & 4.40 & 0.85 \\
\hline Proximity to customers and suppliers & 3.87 & 1.01 & 3.81 & 0.98 \\
\hline Psychological distance & 3.49 & 0.86 & 3.43 & 0.84 \\
\hline Unstable business environment & 3.15 & 0.94 & 3.10 & 0.92 \\
in home country & & & & \\
\hline \hline Profit goals & 4.16 & 0.84 & 3.29 & 0.85 \\
\hline Availability of skilled labour & 4.12 & 0.86 & 4.05 & 0.84 \\
\hline $\begin{array}{l}\text { Availability of unique } \\
\text { product/technological competence }\end{array}$ & 3.60 & 0.88 & 3.54 & 0.85 \\
\hline Desire to reduce risk & 3.35 & 0.87 & 4.09 & 0.82 \\
\hline Foreign ownership's decision & 3.09 & 1.04 & 3.09 & 1.01 \\
\hline
\end{tabular}

Norwegian SMEs) is the lowest among other external motives, pointing out the agreement between respondents on its importance.

Meanwhile, the most important internal motives impacting internationalization of Lithuanian SMEs are profit goals, availability of skilled labour and availability of unique production/technological competence. These findings are in accordance with previous research findings, stating that the profit advantage is one of the most stimulating proactive motivations of the firm to be involved in international activities (Cavusgil, Godiwalla 1982). The standard deviation of profit goals (0.84 of Lithuanian SMEs) is the lowest among other internal motives, pointing out the agreement between respondents on its importance. On the other hand, Norwegian SMEs distinguish such important internal motives as desire to reduce risk, availability of skilled labour and availability of unique product/technological competence. According to international entrepreneurship theory, the motive for internationalization is not necessarily immediate financial gain, but risk avoidance (Prefontaine, Bourgault 2002). The standard deviation of desire to reduce risk ( 0.82 of Norwegian SMEs) is the lowest among other internal motives, pointing out the agreement between respondents on its importance.

Evaluating external and internal barriers to SMEs internationalization, it was taken into consideration that SMEs are less competitive in comparison with large firms. Notably, internal barriers included in the survey allow to make a judgement about capabilities of Lithuanian and Norwegian SMEs related to the competitive threat or a belief what ought to be. The respondents were asked to rank internal and external barriers using Likert scale (where 1 - the least important and 5 - the most important). Possible external and internal barriers to internationalization and findings are listed in Table 2. 
Table 2. External and internal barriers to internationalization

\begin{tabular}{llccc}
\hline \multirow{2}{*}{\multicolumn{1}{c}{ Barriers to internationalization }} & \multicolumn{2}{c}{ Lithuanian SMEs } & \multicolumn{2}{c}{ Norwegian SMEs } \\
\cline { 2 - 5 } & Mean & Stand. deviation & Mean & Stand. deviation \\
\hline Inaccessible market information & 4.38 & 0.91 & 3.14 & 0.75 \\
\hline $\begin{array}{l}\text { Bureaucracy (long administrative } \\
\text { procedures, laws and regulations) }\end{array}$ & 4.38 & 0.74 & 4.46 & 0.83 \\
\hline Intense competition abroad & 4.04 & 0.71 & 3.37 & 0.99 \\
\hline Foreign government restrictions & 3.82 & 0.91 & 3.11 & 0.72 \\
\hline $\begin{array}{l}\text { Differences in consumer habits } \\
\text { and standards }\end{array}$ & 3.51 & 0.96 & 3.12 & 1.18 \\
\hline \hline Start-up costs & 4.00 & 0.81 & 3.09 & 0.72 \\
\hline Limited financial resources & 3.96 & 0.83 & 3.10 & 1.17 \\
\hline Limited management skills & 3.46 & 0.85 & 4.43 & 0.82 \\
\hline Lack of marketing knowledge & 3.22 & 0.84 & 3.12 & 0.74 \\
\hline Communication issues (foreign language) & 2.97 & 1.01 & 3.35 & 0.98 \\
\hline
\end{tabular}

The analysis of survey results allows concluding that the most important external barriers for Lithuanian SMEs are inaccessible market information, bureaucracy and intense competition abroad. Meanwhile, the respondents from Norwegian SMEs indicated bureaucracy, intense competition abroad and inaccessible market information.

The responses of Norwegian SMEs to questions about internal barriers impacting internationalization let us reveal that the firms indicate limited management skills, communication issues and lack of marketing knowledge. Evaluating the most important internal barriers, the respondents from Lithuanian SMEs distinguished start-up costs, limited financial resources and limited managerial skills. Notably, a lack of financial resources restricts the possibility to capture business opportunities abroad. The obtained results correspond with the findings of other researches investigating factors restricting internationalization of SMEs (Johnston, Czinkota 1985). The lack of resources is seen as one of the main factors impacting firm's activities abroad. However, international entrepreneurship theory emphasises that the discovery of opportunities involves knowledge which the entrepreneur uses striving to make own decision. Furthermore, this knowledge is derived from former information and experience in local and foreign markets. Hence, limited managerial skills as one of the main barriers to internationalization, indicated by respondents, allow claiming that the firms do not acquire learning abilities which might transform into international growth. To conclude, limited managerial skills are seen as one of the restricting factors for both Lithuanian and Norwegian SMEs.

The international environment selection of Lithuanian and Norwegian SMEs is based on the main criteria, derived from the stage, network and international entrepreneurship theories. The respondents were asked to rank these criteria using Likert scale (where 1 - the least important and 5 - the most important). The results of findings are presented in Table 3. 
Table 3. The main criteria which determine environment selection

\begin{tabular}{lcccc}
\hline \multirow{2}{*}{$\begin{array}{l}\text { The main criteria of environment } \\
\text { selection }\end{array}$} & \multicolumn{2}{c}{ Lithuanian SMEs } & \multicolumn{2}{c}{ Norwegian SMEs } \\
\cline { 2 - 5 } & Mean & Stand. deviation & Mean & Stand. deviation \\
\hline Geographic proximity & 4.8 & 0.41 & 3.75 & 0.87 \\
\hline Potential growth of markets & 4.4 & 0.49 & 4.3 & 0.46 \\
\hline $\begin{array}{l}\text { Formal relationships with } \\
\text { industry's partners }\end{array}$ & 4 & 0.67 & 4.44 & 0.86 \\
\hline $\begin{array}{l}\text { Accumulated knowledge and varied } \\
\text { experience of entrepreneur }\end{array}$ & 4.2 & 0.61 & 4.53 & 0.77 \\
\hline $\begin{array}{l}\text { Informal relationships with family } \\
\text { members and friends }\end{array}$ & 3.81 & 0.60 & 3.83 & 1.00 \\
\hline $\begin{array}{l}\text { Ability of entrepreneur to gain } \\
\text { support and mobilise resources }\end{array}$ & 3.45 & 0.85 & 3.11 & 0.92 \\
\hline
\end{tabular}

The obtained results about the main criteria which determine selection of international environment allow concluding that Lithuanian SMEs distinguish such criteria as geographic proximity, potential growth of markets and accumulated knowledge and varied experience of entrepreneur. Meanwhile, the respondents from Norwegian SMEs distinguish the most important criteria as accumulated knowledge and varied experience of entrepreneur, formal relationships with industry's partners and potential growth of markets.

Notably, Norwegian SMEs do not emphasise "psychic distance" as the most important criteria for international market selection. Hence, these findings correspond with the claims that "psychic distance" is becoming less relevant as markets become homogeneous and communication and infrastructure improve (Bell 1995). On the other hand, taking into consideration that behaviour of entrepreneur influences the behaviour of the firm, accumulated knowledge and varied experience of entrepreneur is seen as one of the most important criteria in selection of international market.

Responses of respondents to the question how to define the internationalization process of their firms led us to reveal that $32 \%$ of Norwegian SMEs prefer entering new markets through networks, personal contacts and partners. To conclude, collaboration relationships with various partners in the industry are seen as the way to acquire knowledge and experience and to become the entrepreneurial firm. Meanwhile, 38\% of Lithuanian SMEs indicated their internationalization process as step-by-step, risk averse, slow and cautious, i.e. characteristics common to the stage theory.

Questions relating to the operational modes derived from the stage theory were included in the survey instrument. The respondents were asked to rank operational modes using Likert scale (where 1 - the least important and 5 - the most important). The results of findings are presented in Table 4.

Responses of Lithuanian SMEs allow concluding that the most common operational modes are exporting, own representative and subcontracting and licensing. The standard 
Table 4. The operational modes

\begin{tabular}{lcccc}
\hline \multirow{2}{*}{ The operational modes } & \multicolumn{2}{c}{ Lithuanian SMEs } & \multicolumn{2}{c}{ Norwegian SMEs } \\
\cline { 2 - 5 } & Mean & Stand. deviation & Mean & Stand. deviation \\
\hline Exporting & 4.2 & 0.85 & 3.81 & 0.90 \\
\hline Own representative & 4.15 & 0.87 & 4.36 & 0.92 \\
\hline Subcontracting / licensing & 3.63 & 0.89 & 4.4 & 0.88 \\
\hline Joint venture & 3.38 & 0.88 & 3.54 & 0.91 \\
\hline $\begin{array}{l}\text { Own investment abroad / own } \\
\text { production unit }\end{array}$ & 3.12 & 1.05 & 3.09 & 1.09 \\
\hline
\end{tabular}

deviation of exporting ( 0.85 of Lithuanian SMEs) is the lowest among other operational modes, pointing out the agreement between respondents on its importance. The obtained results correspond with the assumptions of the stage theory, stating that exporting is the first choice to gain internationalization experience. Meanwhile, subcontracting and licensing, own representative and exporting are the most common modes for internationalization of Norwegian SMEs. The standard deviation of subcontracting and licensing (0.88 of Norwegian SMEs) is the lowest among other operational modes, pointing out the agreement between respondents on its importance.

\section{Conclusions}

The above research indicates that international decision- making of Norwegian and Lithuanian firms is impacted by external and internal motives. Taking into consideration size of both countries the obtained results of the research allow to claim that small domestic market and competitive pressure from local and international competitors are seen as the main external motives for internationalization. However, the difference of attitudes toward internal motives allows raising the assumption that international entrepreneurship approach prevails in the behaviour of Norwegian firms. Hence, the desire to reduce the business risk and availability of skilled labour are the main internal motives to internationalize.

On the other hand, international decision- making of firms is impacted by external and internal barriers. As for differences between countries, since the market economy is much younger in Lithuania than in Norway, inaccessible market information and high start-up costs are seen as the main barriers to Lithuanian SMEs. Notably, Lithuanian SMEs emphasise geographic proximity as the most important criteria for international market selection. Hence, psychic distance and market knowledge which are defined as the common features of stage model influence the internationalization behaviour of Lithuanian firms. Taking into consideration the main criteria which determine environment selection of Lithuanian firms, the emphasis on exporting seems to be more than justified. The focus of Norwegian firms to subcontracting and licensing allow claiming that Norwegian firms are seen at the more advanced development stage. 
The findings of research allow elaborating proposals for decision- makers of Lithuanian SMEs. The internationalization of firms should combine features of stage, network and international entrepreneurship theories. In the early stages of internationalization geographic proximity has to be seen as the proper way to enter foreign markets. Taking into consideration the experience and more stable performance of Norwegian firms, the barriers to internationalization, namely start up costs and inaccessible market information can be overcome by forming business networks allowing to acquire limited resources and to benefit from the size of networks. The formation of networks expedites the internationalization efforts of SMEs and improves their success rate. On the other hand, entrepreneurial efforts should be taken into consideration as the factor impacting performance of firms. Notably, entrepreneurial efforts are impacted by the most important competences which lay in entrepreneurial knowledge, experience, capabilities and motivation. Management and inter-personal skills are seen as the most important in networking and cooperation with other partners and influence the success of networks' formation. Hence, the competences of entrepreneurs should be developed through training, continuing learning, creating and maintaining networks and relationships. Taking into consideration the experience of Norwegian SMEs, close relationship between government, education institutions and business are vital in exploring business opportunities abroad. From the perspective of government, the assistance to SMEs through various initiatives allowing acquiring information about international markets has significant implications.

The limitations of the presented study were connected with the low response rate of respondents and the fact that SMEs included in the sample represent different business sectors. Further research should therefore concentrate on a deeper analysis of differences between countries and business sectors.

\section{References}

Amdam, R. P. 2009. The internationalisation process theory and the internationalisation of Norwegian firms, 1945 to 1980, Business History 51(3): 445-461.

http://dx.doi.org/10.1080/00076790902844054

Bell, J. 1995. The internationalization of small computer software firms: a further challenge to 'stage' theories, European Journal of Marketing 29(8): 60-75.

http://dx.doi.org/10.1108/03090569510097556

Bell, J.; McNaughton, R.; Young, S.; Crick, D. 2003. Towards an integrative model of small firm internationalisation, Journal of International Entrepreneurship 1(4): 339-362.

http://dx.doi.org/10.1023/A:1025629424041

Bilkey, W. J. 1985. Development of export marketing guidelines, International Marketing Review 2(1): 31-40. http://dx.doi.org/10.1108/eb008268

Buckley, P. J.; Ghauri, P. N. 1993. Introduction and overview, in Buckley, P. J.; Ghauri, P. N. (Eds.). The Internationalization of the Firm. London: Academic Press, 9-21.

Calof, J. L.; Beamish, P. W. 1995. Adapting to foreign markets: explaining internationalization, International Business Review 4(2): 115-131. http://dx.doi.org/10.1016/0969-5931(95)00001-G

Cavusgil, S. T.; Godiwalla, Y. 1982. Decision-making for international marketing: a comparative review, Management Decision 20(4): 47-54. http://dx.doi.org/10.1108/eb001299 
Cavusgil, S. T. 1984a. Differences among exporting firms based on their degree of internationalization, Journal of Business Research 12(2): 195-208.

http://dx.doi.org/10.1016/0148-2963(84)90006-7

Cavusgil, S. T. 1984b. Organizational characteristics associated with export activity, Journal of Management Studies 21(1): 3-22. http://dx.doi.org/10.1111/j.1467-6486.1984.tb00222.x

Cavusgil, T. 1980. On the internationalisation process of firms, European Research 8(6): 273-281. Chetty, S.; Blankenburg-Holm, D. 2000. Internationalization of small and medium-sized manufacturing firms: a network approach, International Business Review 9(1): 77-93.

http://dx.doi.org/10.1016/S0969-5931(99)00030-X

Coviello, N. E.; Martin, K. A. M. 1999. Internationalization of service SMEs: an integrated perspective from the engineering consulting sector, Journal of International Marketing 7(4): 42-66.

Coviello, N. E.; McAuley, A. 1999. Internationalisation and the smaller firm: a review of contemporary empirical research, Management International Review 39(3): 223-256.

De Burca, S.; Fletcher, R.; Brown, L. 2004. International Marketing. A SME Perspective. 2nd edition. Australia: Pearson Education.

Etemad, H.; Wright, R. W. 1999. Internationalization of SMEs: management responses to a changing environment, Journal of International Marketing 7(4): 4-10.

Evangelista, F. U. 1994. Export performance and its determinants: some empirical evidence from Australian manufacturing firms, in Cavusgil, S. T.; Axmin, C. T. (Eds.). 1994. Advances in International Marketing vol. 6. JAI Press, Greenwich, CT, 207-229.

Fletcher, R. 2001. A holistic approach to internationalization, International Business Review 10(1): 25-49. http://dx.doi.org/10.1016/S0969-5931(00)00039-1

Hodne, F. 1993. The multinational companies of Norway, in Jones, G.; Schroter, H. (Eds.). The Rise of Multinationals in Continental Europe. London: Edward Elgar.

Johanson, J.; Mattsson, L. G. 1993. Internationalization in industrial systems - a network approach, strategies in global competition, in Buckley, P. J.; Ghauri, P. N. (Eds.). The Internationalization of the Firm: A Reader. Academic Press, London, 303-322.

Johanson, J.; Vahlne, J. E. 1990. The mechanism of internationalization, International Marketing Review 7(4): 11-24. http://dx.doi.org/10.1108/02651339010137414

Johanson, J.; Vahlne, J. E. 1977. The internationalization process of the firm - a model of knowledge development and increasing foreign market commitments, Journal of International Business Studies 8(1): 23-32. http://dx.doi.org/10.1057/palgrave.jibs.8490676

Johanson, J.; Wiedersheim-Paul, F. 1975. The internationalization of the firm - four Swedish cases, Journal of Management Studies 12(3): 305-322.

http://dx.doi.org/10.1111/j.1467-6486.1975.tb00514.x

Johnston, W. J.; Czinkota, M. R. 1985. Export attitudes of industrial manufacturers, Industrial Marketing Management 14: 123-132. http://dx.doi.org/10.1016/0019-8501(85)90050-1

Karlsson, C.; Dahlberg, R. 2003. Entrepreneurship, firm growth and regional development in the new economic geography: introduction, Small Business Economics 21: 73-76.

http://dx.doi.org/10.1023/A:1025036125745

Katsikeas, C. S.; Piercy, N. F. 1993. Long-term export stimuli and firm characteristics in a Europaen LDC. Journal of International Marketing 1(3): 23-47.

Katsikeas, C. S.; Morgan, R. E. 1994. Differences in perception of exporting problems based on firm size and export market experience, European Journal of Marketing 28(5): 17-39.

http://dx.doi.org/10.1108/03090569410062014

Kaynak, E.; Kothari, V. 1984. Export behaviour of small and medium-sized manufacturers: some policy guidelines for international marketers, Management International Review 24(2): 61-69. 
Knight, G. 2000. Entrepreneurship and marketing strategy: the SME under globalization, Journal of International Marketing 8(2): 12-33. http://dx.doi.org/10.1509/jimk.8.2.12.19620

Leonidou, L. C. 1995. Empirical research on export barriers: review, assessment and synthesis, Journal of International Marketing 3(1): 29-43.

Lu, W. J.; Beamish, P. W. 2001. The internationalization and performance of SMEs, Strategic Management Journal 22: 565-586. http://dx.doi.org/10.1002/smj.184

McDougall, P.; Shane, P. S.; Oviatt, B. M. 1994. Explaining the formation of international new ventures: the limits of theories from international business research, Journal of Business Venturing 9(6): 469-487. http://dx.doi.org/10.1016/0883-9026(94)90017-5

McDougall, P. P.; Oviatt, B. M. 2005. The internationalization of entrepreneurship, Journal of International Business Studies 36(1): 2-8 http://dx.doi.org/10.1057/palgrave.jibs.8400119.

McDougall, P. P.; Oviatt, B. M. 2000. International entrepreneurship: the intersection of two research paths, Academy of Management Journal 43(5): 902-906. http://dx.doi.org/10.2307/1556418

Morgan, R. E. 1997. Export stimuli and export barriers: evidence from empirical research studies, European Business Review 97(2): 68-79. http://dx.doi.org/10.1108/09555349710162571

Okoroafo, D. 1990. An assessment of critical entry factors affecting modes of entry substitution patterns in foreign product markets, Journal of Global Marketing 3(3): 87-104.

http://dx.doi.org/10.1300/J042v03n03_06

Prefontaine, L.; Bourgault, M. 2002. Strategic analysis and export behaviour of SMEs: a comparison between the United States and Canada, International Small Business Journal 20(2): 123-138. http://dx.doi.org/10.1177/0266242602202001

Reid, S. D. 1981. The decision-maker and export entry and expansion, Journal of International Business Studies 12(2): 101-112. http://dx.doi.org/10.1057/palgrave.jibs.8490581

Reid, S. D. 1983. Firm internationalization, transaction costs and strategic choice, International Marketing Review (Winter): 44-56. http://dx.doi.org/10.1108/eb008251

Reiljan, E. 2004. Reasons for de-internationalization: an analysis of Estonian manufacturing companies. Ph.D. University of Tartu, Estonia.

Ruzzier, M.; Hisrich, R. D.; Antoncic, B. 2006. SME internationalization research: past, present and future, Journal of Small Business and Enterprise Development 13(4): 476-497.

http://dx.doi.org/10.1108/14626000610705705

Welch, L. S.; Luostarinen, R. K. 1988. Internationalization: evolution of a concept, Journal of General Management 14(2): 36-64.

Wiedersheim-Paul, F.; Olson, H. C.; Welch, L. S. 1978. Pre-export activity: the first step in internationalization, Journal of International Business Studies 9(1): 47-58.

http://dx.doi.org/10.1057/palgrave.jibs.8490650

Renata KORSAKIENĖ. PhD, works as Associated Professor at Vilnius Gediminas Technical University, Department of Enterprise Economics and Management. Her research interests involve strategic management, innovation management and change management of organizations.

Manuela TVARONAVIČIENĖ. PhD, works as Professor at Vilnius Gediminas Technical University, Department of Enterprise Economics and Management. Her research interests involve tax system reforms in transition economies, investigation of legal tools for conditioning of business environment and factors stimulating investment process in transition economies. 